\title{
UNIDADES SINTÁCTICAS (RECAPITULACIÓN)
}

0.1. En algunos estudios hechos últimamente, he tratado de analizar las estructuras fundamentales del discurso, tanto en su modalidad literaria -ensayo y novela exclusivamente-, cuanto en su realización oral, atendiendo, dentro de esta última, a sus niveles popular y culto. Dado lo reducido del corpus considerado en todas esas ocasiones y debido a la modestia de los propósitos perseguidos, tales trabajos no pasan de ser simples ensayos metodológicos, sencillas pruebas experimentales, cuyos resultados tienen, desde luego, un carácter enteramente provisional.

0.2. En esos intentos de análisis formal, me he servido de varias unidades sintácticas de diversa estructura y de diferente complejidad. Algunas son unidades morfosintácticas bien definidas gramaticalmente; otras son estructuras de forma muy variable y de difícil delimitación gramatical. Se trata de las siguientes: oración, cláusula, frase, prooración, período $\mathrm{y}$, muy secundariamente, oración compuesta.

0.3. En la elección de tales entidades sintácticas atendí a consideraciones básicamente prácticas, más que teóricas, ya que mi principal objetivo era el de descubrir si entre las estructuras propias del habla -culta o vulgar - y de la literatura existían o no diferencias sintácticas apreciables y significativas.

Debo advertir también que, al hacer esa selección y al elegir los términos con que había de denominar a tales estructuras, procuré man- 
tenerme, siempre que me fue posible, dentro de la más estricta tradición gramatical española. Y ello, no por el prurito de bogar contra corriente, sino por la firme convicción de que mantenerse dentro de unos cauces tradicionales bien probados puede ser garantía de acierto y aun de progreso - por cuanto que ael pasado es prólogo»-, y más cuando se trata de una tradición tan antigua y sólida como la de la gramática española clásica, cuyas raíces se entierran en la tradición grecolatina.

0.4. Reúno en estas páginas las ideas fundamentales expuestas dispersa y fragmentariamente en esos trabajos ${ }^{1}$, todos los cuales se complementan entre sí, con el único propósito de presentarlas conjuntamente, por si, revelándose coherentes, pudieran ser de alguna utilidad a quienes proyecten hacer análisis sintácticos de textos orales o escritos.

\section{DELIMITACIÓN PREVIA DE LAS ESTRUCTURAS SINTÁCTICAS}

Como punto de partida, y para evitar equívocos debidos a cuestiones terminológicas, proporciono una definición esencial o provisional de cada una de las unidades sintácticas consideradas.

1.1. Llamo oración al sintagma bimembre entre cuyos dos elementos se establece una relación predicativa. Formalmente responde a la fórmula de Bühler [S $\rightarrow$ P]. Ejemplos:

"Colón descubrió América»; «Los lobos aúllan»; «Las cuentas, claras»; *Qué bello ocaso!».

1.2. La cláusula, en cuanto unidad de manifestación, es la expresión autónoma desde el punto de vista de la elocución. Corresponde a lo que la gramática inglesa moderna denomina sentence $\mathrm{y}$, en esencia, a lo que Andrés Bello dio en llamar oración. No tiene una forma gramatical determinada, puesto que puede estar constituida por una sola palabra -interjección, vocativo, etc.- por un sintagma nominal o adverbial, por una frase, por una oración o por uno o varios períodos.

1 Me refiero a los siguientes: «Gramática y aprendizaje de la lengua materna», Boletín de la Academia Puertorriqueña de la Lengua, VI, 1978, págs. 43-71; «La cláusula y el análisis del discurso», Nueva Revista de Filología Hispánica, XXVIII, 1979, págs. 1-29; El concepto de oración en la lingüistica española, UNAM, 1980; *La estructura del discurso en cinco escritores mexicanos», en Festschrift for Jacob Ornstein, Rowley, Mass., Newbury Publ., 1980, págs. 165-173; «La estructura de la cláusula en el habla y en la literaturax, Anuario de Letras, XVII, 1979, págs. 97112; «El concepto de oración compuesta», Boletín de Filologia, Chile, XXX, 1979, págs. 91-104. 
Lo que la define y delimita es, pues, su autonomía dentro del acto de la comunicación. Ejemplos:

« ¡Caramba!»; «En mi casa» o «Por la noche» 2; «Buenos días»; « iLa nostalgia de los años perdidos!»; "Ya me voy»; «Si lo ves, dile que venga a mi casa en cuanto puedax.

1.3. Entiendo por frase la expresión constituida en torno a un elemento nuclear - generalmente un nombre - pero no organizada de acuerdo con la estructura $[S \rightarrow P$ ]. Su contenido puede corresponder al de una oración, pero se distingue de ésta por la manera de estructurar sus elementos constitutivos: en la frase no se establece la relación predicativa esencial en toda oración. Ejemplos:

«Tanto esfuerzo para nada»; «iLa esperanza de un retorno feliz!»; «Una limosna, por caridad».

1.4. Denomino prooración al morfema o sintagma de estructura no oracional que implica -reproduce- una oración ya enunciada. Por ejemplo: « ¡Nunca! * como respuesta a una pregunta del tipo * ¿Cuándo me lo vas a dar?»; o «Por la noche» en casos como los ejemplificados en la nota 2.

1.5. Llamaré período a la expresión constituida normalmente por dos -0 , a veces, varias- oraciones o frases entre las cuales se establece una sola relación sintáctica, ya hipotáctica, ya paratáctica. Ejemplos:

«Si vienes, te lo daré»; «Se lo regalas o se lo prestas o se lo vendes»; « ¡Tanto esfuerzo inútil y tanta ilusión frustrada! ».

1.6. Reservo el nombre de oración compuesta a cierta clase de períodos caracterizados por el hecho de que uno de los elementos nucleares de la oración gramatical, [S] o [P], es, a su vez, una oración:

«Quien canta su mal espanta»; *Tú fuiste el que le engañó.

1.7. De lo dicho hasta aquí se desprende que los conceptos de oración, período (y oración compuesta), frase y prooración pertenecen a un nivel diferente del que corresponde a la cláusula. Los primeros se excluyen entre sí, pero ninguno de ellos es excluyente de la cláusula. Una oración, en efecto, no puede ser a la vez frase o periodo, ni éste puede ser prooración o frase, etc. Pero cualquiera de ellos puede constituir una cláusula, siempre que aparezca como expresión autónoma dentro del discurso, conforme indicaba en $\S 1.2$.

2 En respuestas a preguntas como « ¿Dónde nos reuniremos?» o «Cuándo vendrás?» respectivamente. 


\section{LA ORACIÓN GRAMATICAL}

\subsection{Historia del concepto en la gramática española.}

2.1.1. Los primeros gramáticos castellanos tuvieron un concepto básicamente - por no decir que exclusivamente- formal de la oración. Para ellos, en efecto, oración era toda expresión constituida en torno a un nombre y un verbo debidamente concertados. La fórmula que responde a sus definiciones es, estrictamente, [N-V].

Si bien Nebrija no proporciona una definición precisa y en su Gramática $^{3}$ alternan un tanto confusamente los términos oración, cláusula y sentencia, muy pronto habría de quedar establecido que los elementos esenciales, nucleares, de la oración gramatical son el nombre y el verbo. Lo apunta ya, explícitamente aunque de pasada, el Doctor Bernabé de Busto 4, cuando dice: «Hasta aquí se ha tratado del nombre y verbo: que son partes principales en la orazión».

Pocos años después, el Licenciado Villalón ${ }^{5}$ establecía en nuestra gramática la definición que habría de hacer suya toda la escuela linguiística española del Renacimiento; para él, la oración «se liga y vñe de partes nombre y verbo como de prinçipales: y de otras menos prinçipales» (pág. 56); o más pormenorizadamente

oraçión, es vna composiçión de nombre y verbo y pronombre como de partes prinçipales: y de otros muchos vocablos y diciones, como de partes menos prinçipales: como de aduerbios, preposiçiones, interjeçiones y conjunçiones (pág. 50).

El carácter constitutivo, nuclear, del nombre y del verbo como elementos indispensables de la oración se reitera con todo rigor en la trascendental obra de Francisco Sánchez de las Brozas ${ }^{6}$. Comenzando por el cap. 12 del lib. I: «Plato... aperte docet, sine nomine et verbo nullam constare orationem». Continuando por el cap. 2 del lib. II: $\star$ Ex Nomine et Verbo, tanquam ex materia et forma, quae brevissima sit, constituitur oration. $Y$ terminando por el cap. 1 del lib. III, donde precisa que el nombre debe aparecer en nominativo, esto es, funcionando como sujeto: «nam sine nomine \& verbo non sit oratio. Nomen voco

3 Antonio de Nebrija, Gramática castellana, Salamanca, 1492. (Cito por la ed. de P. Galindo Romero y L. Ortiz Munoz, Madrid, 1946).

4 Introductiones grammaticas, breves $\tau$ compendiosas, Salamanca, 1533, Lib. III.

5 Gramática castellana, Amberes, 1558. (Cito por la ed. facs. de Constantino García, Madrid, 1971).

- Francisci Sanctir Brocbnsis, Minerva, seu de causis linguae latinae commentarius. (Cito por la ed. de Ulyssipone, 1760). 
rectum ipsum cum Aristotele». En este mismo capítulo apunta el Brocense la necesidad de que entre el nombre y el verbo se establezca una relación predicativa como fundamento de toda oración gramatical.

Aunque en las breves Instituciones de Jiménez Patón ${ }^{7}$ no se da una definición concreta de la oración, lo que de pasada anota y los ejemplos que de oraciones proporciona permiten suponer que su concepto coincidía con el de Villalón y el Brocense. Coincide con él, plenamente, el de Gonzalo Correas ${ }^{8}$. El pasaje de su Arte donde con mayor detalle define a la oración dice así:

Desta orazion, que io llamo gramatical, habla prinzipal i propiamente la Gramatica, aunque no la veo definida en las Artes: io la difino, descrivo i declaro desta manera: Orazion es la rrazon i sentido 6 habla conzertada que se haze con nonbre i verbo de un mesmo numero i persona, el nonbre en nominativo, $i$ el verbo en cadenzia ó persona finita, no infinitivo, $i$ se adorna con la particula si quiere, $i$ con otros casos destas partes, $i$ con ellas mesmas rrepetidas. Las partes forzosas desta orazion son el nonbre i el verbo. La particula es azesoria (pág. 132).

Capítulos después, al analizar las funciones del sustantivo, repite la idea:

El nonbre esta en la orazion para mover, $i$ aconpañar al verbo, $i$ hazer anbos la orazion, porque sin el uno $\delta$ el otro, no se puede hazer sentenzia, ni dezir nada. El nonbre á de ser sustantivo, puesto en nominativo por la persona que haze $\delta$ se haze ó si queremos dezir padeze (pág. 366).

Estas definiciones renacentistas, basadas en la relación gramatical existente entre un nombre y un verbo [N-V], llegaron, a través de diversos autores", hasta las primeras ediciones de la Gramática académica ${ }^{10}$. En ellas se sostiene que «no puede haber oración ni sentido alguno donde falte verbo regido por un nombre sustantivo, 6 pronombre expreso ó suplido» (ed. de 1796, pág. 289) "1. Y con otras palabras, páginas antes:

7 Bartolomé Jiménez Patón, Epitome de la ortografía latina y castellana. Instituciones de la gramática española. Ed. de Antonio Quilis y Juan M. Rozas, Madrid, 1965.

8 Arte de la lengua española castellana, 1625. Ed. de Emilio Alarcos García, Madrid, 1954.

- Como Benito Martinez Gómez Gayoso (Gramática de la lengua castellana, Madrid, 1769) quien afirmaba: «De estas nueve [partes de la oración], las más nobles, y principales son el Nombre, y el Verbo; porque sin ellas no se puede formar oración perfecta» (pág. 31).

10 Real Academia Española, Gramática de la lengua castellana, 1.^ ed., Madrid, 1771. (Cito por la 3.a impresión, Madrid, 1781, y ediciones sucesivas).

11 Cosa que ya se había dicho en la primera edición, con el solo cambio del término oración por el de proposición, cfr. pág. 244. 
Estas dos partes [nombre y verbo] son tan precisas para formar la oracion, que ni puede haber oracion sin ellas, ni tampoco verbo sin nominativo, 6 nominativo sin verbo, callado o expreso (pág. 281).

2.1.2. A partir del siglo XIX, las definiciones formales de la oración, sometidas a la influencia de la lógica, prefieren considerar que los elementos constitutivos de esa estructura gramatical son el sujeto y el predicado ${ }^{12}$. La fórmula esquemática se transforma en [S-P].

Todos los gramáticos modernos siguen reconociendo la personalidad de esa estructura bimembre predicativa [S-P], pero son ahora muchos los que prefieren darle el nombre de proposición, para reservar el de oración a la expresión de sentido completo o sintácticamente autónoma. Sin embargo, no faltan hoy quienes siguen otorgando el tradicional nombre de oración a esas expresiones básicas estructuradas en torno a un [S] ujeto y a un [P]redicado. Así lo hacen, entre otros, Rafael Seco, para quien la oración consta siempre de «sujeto y predicado» ${ }^{13}$. 0 Manuel Criado, según el cual «en la oración se oponen dos miembros bien definidos: el predicado o «lo que se dice» y el sujeto «de quien se dice» ${ }^{14}$. O Pérez-Rioja, en cuya opinión los «elementos esenciales de la oración [son] sujeto y predicado» ${ }^{15}$. Idéntico concepto, presentado con mayor precisión, es el que revela Emilio Alarcos Llorach: «Gramaticalmente, en [expresiones oracionales] no tenemos más que un sujeto y un predicado, conectados por la relación predicativa que es la que constituye toda oración y es señalada por ciertos indicios formales (la llamada concordancia de número y persona)» ${ }^{16}$. $Y$, aunque sin detenerse en razonamientos téricos pormenorizados, también Rodríguez Adrados, al establecer las diferencias existentes entre oración de un lado y palabra o sintagma del otro, observa que en estos últimos no hay "la relación sujeto-predicado que existe en la oración» ${ }^{17}$.

2.1.3. A fines del siglo XviII, Juan de Iriarte rompió con esa tradición clásica, que había establecido la distinción entre oración -estructura bimembre predicativa- y cláusula -oración o conjunto de oraciones con sentido completo (cfr. § 7.1). Iriarte, en efecto, prefirió

12 O el sujeto y el verbo, como prefiere decir JaIME Costa de Vall. (Nuevo método de gramática castellana, 3." ed., Barcelona, 1830): «No puede haber oración que no conste de sujeto y verbo, espresos o suplido el unow (pág. 123).

13 Manual de gramática española, Madrid, 1930. (Cito por la ed. de Manuel Seco, Madrid, 1954), pág. 7.

14 Gramática española, Madrid, 1958, pág. 41.

15 José ANtonio Perez-RIojA, Gramática de la lengua española, Madrid, 1953. (Cito por la 2.^ ed., de 1957), pág. 292.

16 Estudios de gramatica funcional del español, Madrid, 1970, pág. 111.

17 Lingütstica estructural, 2 vols., Madrid, 1969, pág. 45. 
considerar que la oración era la expresión total, completa, en tanto que a las estructuras predicativas de forma [S-P] las denomina frases o sentencias. Así -explica- los enunciados predicativos Imperator jubet y Milites parent (o «el General manda» y «los soldados obedecen») no son sino frases (o sentencias) de la oración «Imperator jubet, ac Milites parent ${ }^{18}$.

Andrés Bello hizo suya, varias décadas después, esta doctrina, aunque sustituyendo el nombre de frase por el de proposición, término ya utilizado por varios gramáticos con anterioridad ${ }^{19}$. Bello ${ }^{20}$, en efecto, opina que «el sujeto y el atributo [predicado] unidos forman la proposición (\$ 35), en tanto que «se llama oración toda proposición o conjunto de proposiciones que forman sentido completo; de que está alfombrada la ribera es proposición perfecta, pero no es oración* $(\S 308)^{21}$.

La opinión de Bello parece haber hecho fortuna entre muchos gramáticos españoles e hispanoamericanos modernos-Cejador ${ }^{22}$, Amado Alonso y Pedro Henríquez Ureña ${ }^{23}$, Rafael A. de la Peña ${ }^{24}$ - y especialmente contemporáneos -José Roca Pons ${ }^{25}$, César Hernández Alonso ${ }^{26}$, Manuel Seco ${ }^{27}$, J. Alcina y J. M. Blecua ${ }^{23}$ y J. Escarpanter ${ }^{29}$ - entre los cuales sospecho que ha pesado, más que la opinión de Bello, la de Leonard Bloomfield y otros gramáticos de lengua inglesa seguidores suyos ${ }^{30}$.

18 Gramática latina, 6.: ed., Madrid, 1804, pág. 235.

19 Como, por ejemplo, el Padre Benito de SAN PEDro (Arte del romance castellano, Valencia, 1769, II, pág. 2), o JAIMe Costa DB VALL (Nuevo método de gramática castellana, 3.* ed., Barcelona, 1830, págs. 142-143), o Vicente SalVa (Gramática de la lengua castellana, Paris, 1830. Cito por la 5." ed., Valencia, 1840, pág. 1).

20 Gramática de la lengua castellana. En la edición de las Obras completas, Caracas, 1951. (La 1.: ed. es de 1847).

21 Aunque claro está que hay oraciones sintácticamente subordinadas que sí poseen «sentido completo», como yo estoy enfermo en la cláusula ase preocupa mucho porque yo estoy enfermo» (cfr. infra, \$ 8.3.).

22 Julio Cejador y Frauca, La lengua de Cervantes, 2 vols., Madrid, 1905-1906.

23 Gramática castellana, 11.* ed., 2 vols., Buenos Aires, 1951 y 1953.

24 Gramática teórica y práctica de la lengua castellana, 2.* ed., México, 1900. Los detalles de esta particular historia los proporciono en el librito sobre El concepto de oración en la lingüistica española citado en la nota 1.

25 Introducción a la Gramática, 2 vols., Barcelona, 1960.

26 Sintaxis española, Valladolid, 1970.

27 Gramática esencial del español, Madrid, 1974.

28 Gramática española, Barcelona, 1975.

29 Introducción a la moderna gramática española, Madrid, 1974.

30 Cfr. Leonard Bloompieid, Language, New York, 1933, pág. 171; Charles F. HockeTt, $A$ course in modern linguistics, New York, 1958, págs. 203-204; JoHN LYoNs, Introduction to theoretical linguistics, London-New York, 1968, págs. 171 y 178-180. Entre Bello y Bloomfield hay que situar necesariamente, para hacer justicia a la historia linguifstica, a ANTOINE MeILLET, Introduction a l'etude comparative des 
No obstante la autoridad de tantos y tan famosos gramáticos de nuestros tiempos, considero que, en los términos en que ellos establecen la antinomia «proposición/oración», no superan a la establecida por la gramática española clásica entre «oración/cláusula», sino que más bien la deterioran. De ello volveremos a ocuparnos en el § 8. Baste, por ahora, apuntar que, para definir lo que ellos llaman xoración» (y los ingleses sentence), atienden a la «plenitud semántica» o a la «autonomía elocutiva» de las expresiones analizadas, esto es, a consideraciones ajenas a la forma o a la función sintáctica de tales expresiones. Y no me parece debido olvidar que la Gramática o morfosintaxis es la ciencia que estudia las funciones de las formas lingüísticas. Luego el término oración puede y debe seguirse usando para designar a la unidad fundamental de la Gramática. Esas definiciones modernas corresponden a lo que nuestros gramáticos clásicos - con una sensibilidad etimológica innegable - habían llamado cláusula.

\subsection{Validez del concepto tradicional de «oración».}

2.2.1. Definir la oración - de acuerdo con la fórmula simbólica [S $\leftarrow \mathrm{P}$ ] - como estructura bimembre en que se establece una relación predicativa es dar una definición estrictamente gramatical, morfosintáctica, por cuanto que ella atiende a la forma de las expresiones que deben considerarse oracionales y a la función que entre sus elementos constitutivos se realiza.

Cierto que el esquema [N-V] con que podríamos representar simbólicamente las definiciones renacentistas ('nombre y verbo en relación predicativa') no cubre todas las posibilidades de las estructuras que, sin duda, son oracionales. $Y$ ello, básicamente, por dos razones: porque puede haber oración (relación predicativa) sin la presencia de un nombre -en sentido estricto-, y porque también puede haber oración sin necesidad de que aparezca un verbo morfológico.

Aunque la concepción, más amplia o menos marcada, que simboliza la fórmula [S $\leftarrow \mathrm{P}$ ] entendida como 'relación entre un sujeto y un predicado', supera el segundo de los inconvenientes señalados, tampoco cubre, en verdad, todas las posibilidades de las estructuras oracionales. Y ello por la sencilla razón de que hay oraciones sin verdadero sujeto gramatical: "Hubo toros» o «Me fue bien en el examen».

langues indo-européennes, Paris, 1903 y, sobre todo, a OTro JESPERSEN, The philosophy of grammar, London, 1924. (Cito por la ed. de London, 1958, págs. 114 y 307). Con posterioridad a Bloomfield hay que recordar, en Francia, a ANDRE MARTINET, Eléments de linguistique générale, Paris, 1960, págs. 122-123. 
Sin embargo, pienso que no hay por qué repudiar la fórmula. Basta con ampliar sus alcances, siguiendo para ello la pauta marcada por Karl Bühler.

2.2.2. Débese recordar que, para Bühler, «la formula $S \rightarrow P$ de la lógica aristotélica sólo debe indicar que la formación tiene dos miembros y cierto grado de asimetría en su estructura» ${ }^{31}$, asimetría que depende del carácter predicativo del elemento $[P]$, cosa que hace inalterable tal fórmula: [P] se predica de [S], pero no [S] de [P]. Así entendida, la fórmula es aplicable no sólo a expresiones estructuradas en un sujeto gramatical y un predicado, sino también a elocuciones como las siguientes:

(1) A María le fue bien en el examen.

(2) Hubo toros.

(3) iQué bello ocaso!

(4) Año de nieves, año de bienes.

Aunque en los ejemplos del tipo (1) y (2) no exista un sujeto gramatical estricto, sí aparece un elemento nominal -María y los toros respectivamente- del que el otro elemento predica algo: el éxito (el ir bien), en el primer caso, y la existencia (su celebración: el haber), en el segundo. De igual manera, aunque en los ejemplos del tipo (3) y (4) no figure un verbo, sí aparece un elemento predicativo preciso: en (3), la belleza que advertimos en ese ocaso, y en (4), la bondad (los bienes) de los años en que se producen nevadas frecuentes.

El [P]redicado puede estar constituido no sólo por un elemento verbal («Fulano está durmiendo») o nominal ( Las cuentas, claras»), sino también por un elemento adverbial: «Los barítonos, más fuerte»; «Los niños, delante»; «La solución, mañana». Todas éstas son estructuras evidentemente oracionales, que encajan sin dificultad dentro del esquema $[S \leftarrow P]$.

Parecen no encajar en él dos tipos de expresión particular: las interjecciones y los verbos unipersonales.

2.3. Oraciones formadas en torno a un verbo unipersonal, del tipo «llueve», «nieva» 0 *anochece».

2.3.1. Para explicarlas dentro de la concepción bimembrista [S $\leftarrow \mathrm{P}$ ] de la oración, no creo que haya que recurrir a interpretaciones un tanto forzadas, como la que propuso el propio Bühler, para quien el bimembrismo de esas expresiones se establecería mediante la relación entre

31 Teoria del lenguaje, 3.* ed., Madrid, 1967, pág. 539. 
fenómeno y lugar. De acuerdo con ello, la oración completa y equiparable, por ejemplo, a Cayo duerme, no sería llueve, sino llueve en el lago ${ }^{32}$, donde ya figuran dos elementos sintácticos diferentes. Sin embargo, esta explicación no parece satisfactoria, porque no hay relación predicativa entre sus miembros y porque, como ha observado L. J. Piccardo ${ }^{33}$, «tales determinaciones de lugar son, por su forma, idénticas a las que acompañan a los demás verbos» sin originar por ello estructura oracional; ay la gramática, como lo ha señalado el propio Bühler, no puede nunca dejar de lado el aspecto formal».

Tampoco parece acertado inventar sujetos más o menos «lógicos» para tales verbos, según han hecho no pocos lingüistas de muy diversas épocas. Como, por ejemplo, Francisco Ipiña ${ }^{34}$, para quien el sujeto no puede ser otro que Dios o la Naturaleza: «En los verbos Exceptae actionis, como pluit, ningit, grandinat, tonat... se entiende Deus, $6 \mathrm{Na}$ tura; porque sus acciones se atribuyen solo á Dios, ó á la naturalezax. Explicación que hizo suya la Real Academia desde las primeras ediciones de su Gramática y ha conservado hasta la última, de 1962; «Los verbos unipersonales llevan callado el sujeto, por ser muy determinado. En latín es Jupiter; en griego Zeus, y en castellano, Dios, el Cielo o la Naturaleza (\$ 283a).

2.3.2. Mucho más convincente parece la explicación propuesta por Sánchez de las Brozas - basándose, posiblemente, en Prisciano- según la cual el agente o, mejor, el sujeto sería el fenómeno mismo, implícito en el verbo atmosférico de que se trate: la lluvia en el caso de llover, el trueno en el de tronar, la noche en el de anochecer, etc. He aquí las palabras del Brocense: «Plato asserit, sine Nomine \& Verbo nullam effeci posse orationem... Idem intellige in verbis quae dicuntur Naturae; ut pluit, ningit, lucescit, subaudi pluvia, nix, lux... Integra ergo est oratio: pluit pluvia, fulget fulgur, lucescit lux»35.

Esta explicación ha tenido decididos defensores en nuestro siglo; entre ellos, muy denodadamente, Julio Cejador, y además V. García de Diego ${ }^{36}$, Angel Lacalle ${ }^{37}$, Pérez-Rioja ${ }^{36}$ y Rafael Seco ${ }^{37}$, quien descubría la existencia de un «sujeto interno» extraído de la propia raíz verbal:

32 Cfr. K. BţHere, ob. cit., pág. 553.

33 El concepto de oración, Montevideo, 1954, pág. 8.

34 Francisco IpiNa y Cervantes, Syntaxis praeceptiva, Toledo, 1694, pág. 11.

35 Minerva, lib. IV, cap. 3, pág. 537 y lib. III, cap. 1, pág. 262.

36 Lecciones de lingulistica española, Madrid, 1951. Lingüistica general y española, Madrid, 1951 y Manual de gramática castellana, Madrid, 1917.

37 Gramática española, Barcelona, 1942, pág. 227.

33 Gramática de la lengua espafiola, pág. 398, § 376.

39 Manual de gramática española, pág. 186. 
«Los verbos que expresaran los fenómenos de la naturaleza, llover, tronar, diluviar..., etc., no ofrecen propiamente posibilidad de que se les atribuya un sujeto gramatical, gracias a su especial significado de hechos naturales... Realmente, en estos verbos lo que hay es un sujeto interno, sacado de su propia raíz; así, la lluvia es la que llueve y el trueno es el que truenax.

También Charles Bally ${ }^{* 0}$ se resistía a admitir «la afirmación de que la desinencia en latín tonat, esp. llueve, ital. piove, así como el pronombre sujeto en fr. il tonne, son formas vacías», y consideraba que «il puede afirmar la existencia de un fenómeno especial (il pleut = 'hay lluvia')... o bien un agente desconocido e indeterminado ('algo produce lluvia, hace lluvia')». Que el pronombre il del francés no sea un signo vacío ya lo habian sostenido tajantemente A. Arnauld y C. Lancelot: «Et quand nous disous il pleut, il nege, il gresle, etc., il est là pour le nominatif, c'est à dire, pluie, nege, gresle, etc., renfermé avec leur verbe substantif est ou fuit: comme qui diroit, il pluie est, il nege se fait " 41.

Expresiones del tipo pluit pluvia se documentan en diversas lenguas. Bally recuerda los casos del ruso grom gremít ('el trueno truena'), del alemán der Regen regnet ewig fort ('la lluvia llueve' en Chamisso) y otros. En el sur del Matto Grosso se canta todavía una antigua copla que dice: «Chuva choveu, Coxipó encheu». Y en el polaco del siglo pasado deszcz dzdzy ('lluvia llueve') junto al normal pada deszcz ('cae lluvia') o deszczu ('llueve').

Cabría suponer que esos verbos unipersonales son el resultado de un proceso originado a partir del sustantivo que denomina al fenómeno, y no lo contrario, como supusieron Rafael $\operatorname{Seco}^{12}$ y, en su seguimiento, A. Lacalle ${ }^{43}$, Pérez-Rioja ${ }^{4}$ y aun la Academia ${ }^{45}$. Es decir que no es que de la raíz verbal se extraiga un sujeto interno, sino que el nombre designador del fenómeno genera un verbo cognado ${ }^{\text {t5 }}$, que acaba por «absorber» al sustantivo sujeto. Así, partiendo del sustantivo «la lluvia»,

40 «Impresionismo y gramática». En el libro El impresionismo en el lenguaje, ed. por A. Alonso y R. Lida, Buenos Aires, 3.* ed., 1956, págs. 15-44; la cita en las págs. 18-19.

41 Grammaire générale et raisonnée ou La Grammaire de Port-Royal. Edition critique présentée par Herbert E. Brekle. (Ed. facs. de la 3.^ ed., de 1676), StuttgartBad Cannstatt, 1966, pág. 129.

12 Manual de gramática española, pág. 186.

4 Gramática española, \$265.

- Gramática de la lengua española, \$ 376.

45 Gramatica de la lengua castellana, \$ 3.5.7.

46 Como insinuaba el Brocense: aIn verbis, quae falso dicuntur naturae, ut pluit, placet Linacro et doctis intelligi suppositum cognatae significationis» (lib. III, cap. 1). 
se afirma su existencia, su realización: «la lluvia es (se produce, cae)»; este «ser la lluvia» daría origen a un verbo llover (un «llover la lluvia*, por supuesto), que haría innecesaria ya la expresión del sustantivo sujeto.

Para la denominación de los fenómenos atmosféricos, se sirve la lengua de dos tipos de expresión, igualmente aimpersonales». De un lado, la forma unimembre constituida por un verbo unipersonal: llueve, graniza, anochece, relampaguea, etc. De otro, la expresión bimembre constituida por un sustantivo designador del fenómeno y por un verbo de significado «neutro»: hace calor, hay sol, hace viento, hay un terremoto, ruge la tormenta, etc. La afinidad existente entre estas dos clases de expresiones había sido ya señalada por Arnauld y Lancelot ${ }^{47}$, quienes analizaban las estructuras del tipo il fait chaud como equivalentes de las del tipo il neige. $Y$ en español, hay lluvia es lo mismo que llueve, como hay sol sería - podría ser- lo mismo que *solea. Y si nevar es lo mismo que caer nieve, y diluviar, lo mismo que caer un diluvio, paralelamente caer (un) rayo(s) sería - podría ser- *rayear (cfr. relampaguear).

Prueba de la dirección que supongo en el proceso derivativo podría ser también el hecho de que en todos los verbos unipersonales aparece una raíz nominal (llover-lluvia, tronar-trueno, nevar-nieve, anochecernoche, etc.), en tanto que son muchos los fenómenos atmosféricos que cuentan sólo con una designación nominal, pero no con la verbal corres. pondiente a su proceso: terremoto, huracán, ciclón, sismo, chaparrón, aguacero, etc., sin que exista *terremotear, *huracanar, *ciclonear, *chaparronear, etc. $Y$ parece ser prueba también de esa dirección que imagino el hecho de que toda expresión verbal (unimembre) pueda ser enunciada en sus dos elementos constitutivos, en tanto que no todas las estructuras bimembres pueden expresarse -todavía, al menosen forma sintética: llover $\rightarrow$ caer la lluvia, atardecer $\rightarrow$ caer la tarde, relampaguear $\rightarrow$ saltar un relámpago, etc., pero no hacer sol $\rightarrow{ }^{*}$ solear, ni hacer calor $\rightarrow{ }^{*}$ calorear, ni caer un rayo $\rightarrow$ *rayear, etc.

\subsection{Interjecciones y locuciones interjectivas.}

2.4.1. En el análisis y clasificación de las interjecciones ha habido, dentro de la escuela gramatical espafiola, actitudes y soluciones para todos los gustos imaginables. Podrían resumirse, muy esquemáticamente, en las siguientes:

17 Grammaire générale et raisonnée ou La Grammaire de Port-Royal, pág. 129. 
a) las interjecciones son una parte de la oración, ya sea que se incluya en la categoría de los adverbios (Nebrija), ya que se considere categoría independiente (Busto, Villalón, Correas, J. Villar ${ }^{*}$, Costa, etc.)

b) las interjecciones son verdaderas oraciones completas 0 , por 10 menos, equivalentes de oración, por cuanto que ellas solas, por sí mismas, pueden revelar nuestros sentimientos tan plenamente como una oración gramatical (Salvá, Bello, Lacueva, Selva, Marín, Lamíquiz, etc.; y Benot, Lenz, Amado Alonso, Gili Gaya, Barrenechea, César Hernández, etc.).

c) las interjecciones no son ni partes ni equivalentes de oración, ni mucho menos oraciones verdaderas.

d) las interjecciones no son ni siquiera elementos gramaticales.

La decisión depende, claro está, de la actitud que se adopte ante el hecho del habla, de los principios de acuerdo con los que se analice el fenómeno linguiístico. Una actitud gramatical, morfosintáctica, puede ayudar a esclarecer el problema.

2.4.2. Ante todo, parece de suma importancia la distinción que estableció la Real Academia, en las primeras ediciones de su Gramática *, entre lo que podría llamarse propiamente interjección y la locución interjectiva: «No se deben considerar como interjecciones sino aquellos breves sonidos, $\delta$ voces cortas en que el ánimo prorrumpe casi involuntariamente ${ }^{50}$ para desahogo suyo, 6 para advertir alguna cosa a otro... Las expresiones que constan de dos, o más voces, y que algunos llaman interjecciones, como: gracias á Dios, bendito sea Dios, Jesús mil veces, y otras semejantes, no deben considerarse como interjecciones, sino como verdaderas oraciones, que, quando mas, necesitan suplemento de algún verbo: ${ }^{\mathbf{5 1}}$.

2.4.3. De acuerdo con esta distinción, es obvio que las interjecciones propiamente dichas no son parte de la oración, por la sencilla y evidente razón de que - como indicaron Alonso y Henriquez Ureña ${ }^{2}$ la interjección «no entra a formar parte ni de la estructura del sujeto ni de la del predicado» (II, § 223), sino que sólo acompañan tangencialmente a las estructuras oracionales como refuerzo expresivo.

2.4.4. Tampoco pueden considerarse ni equivalentes de oración ni mucho menos oraciones verdaderas. No son esto último por cuanto que

48 Arte de la lengua espantola, Valencia, 1651.

- Cfr. la ed. de 1781, pág. 235.

so Cfr. Garcta de Dirgo, Lingülstica general española, pág. 44.

51 Expresiones interjectivas llamó a estas ultimas MAriano dB Remrnterfa (Conferencias gramaticales sobre la lengua castellana, Madrid, 1843, pág. 126), haciéndose eco de la acertada distinción académica.

52 Ob. cit., II, § 223.

LXI. -4 
la interjección no está gramaticalmente estructurada en [S $\leftarrow \mathrm{P}$ ]. Ni son, en verdad, equivalentes de oración, por cuanto que tal equivalencia descansaría sólo en razonamientos semánticos, y la oración gramatical no ha quedado definida por su contenido (semánticamente), sino por su forma y su función (morfosintácticamente). La supuesta equivalencia oracional de la interjección se aproxima, así, a la equivalencia oracional de un gesto o de un semáforo... En cambio, la interjección sí puede relacionarse con la cláusula, unidad nocional, conforme después veremos.

2.4.5. En lo que respecta a las locuciones o expresiones interjectivas, cabe decir que ellas serán, desde el punto de vista gramatical, lo que sus elementos constitutivos les hagan ser formalmente: simples vocativos (como en ¡Maria!), frases (como en ¡Gracias a Dios!), prooraciones (como en - iNunca!) u oraciones verdaderas (como en iMaldita sea tu estampa!). Lo único que distingue o marca a estas expresiones de las correspondientes normales - no interjectivas- es el rasgo exclamativo propio de su particular entonación ${ }^{53}$.

\section{LA FRASE}

3.1. Para manifestar el contenido de su conciencia, dispone el hablante no sólo de la estructura oracional $[S \leftarrow P$ ], sino también de otras formas de expresión de naturaleza diferente. Decía antes (cf. § 1.3) que puede darse el nombre de frase a la expresión autosemántica constituida por un elemento nuclear o en torno a un elemento nuclear -en la inmensa mayoría de los casos, un sustantivo-, pero de estructura no oracional, es decir, no articulada en [S] y [P]. Cuando se habla de estas unidades formales, suele afirmarse que se trata de oraciones elípticas o de restos o equivalentes de oración. No dudo de que, conceptualmente, sea cierta tal equivalencia ${ }^{54}$, pero desde el punto de vista formal se trata de entidades bien diferenciadas. La frase puede ser unimembre, cosa que no sucede en el caso de la oración; y esencial en ésta es la relación predicativa, relación que no aparece en la frase. En efecto, ¡Fuego! o Una limosnita son frases unimembres; y en La emoción de un viaje a la India, los elementos constitutivos se organizan por

53 Son, pues, estructuras gramaticales -oraciones o no- enunciadas de una manera particular. Como también las expresiones interrogativas son enunciados particulares desde el punto de vista de la entonación.

54 Aunque no hay que olvidar que la oración gramatical no ha quedado definida conceptualmente. 
subordinación sucesiva (núcleo + compl. adnominal + compl. locativo), sin que aparezca la relación predicativa entre ninguno de ellos. Cierto que existe cierta correspondencia entre esta última frase y una posible oración gramatical «El viaje a la India nos emocionaba», pero tal paralelismo es únicamente semántico, no formal. Prueba de ello es que el mismo contenido podría expresarse a través no ya de una oración gramatical, sino de un período sujetivo: «Nos emocionaba viajar a la Indiax.

Frase y oración son, pues, unidades gramaticales $-\mathrm{y}$, en cuanto tales, afines o xemparentadas - pero formalmente diferentes. Su afinidad gramatical ${ }^{55}$ les permite establecer relaciones sintácticas entre sí: Una oración puede regir a una frase («Entonces Fulano gritó: ¡Al diablo con todo eso! »), así como una frase puede regir a una oración gramatical: «Tanto esfuerzo inútil, pero no debemos cejar en nuestro empeño»; « ¡Socorro, que me caigo! ». Claro está que dos o más frases pueden combinarse entre sí: «Sumisión en su actitud corporal, pero odio en su mirada esquivax.

3.2. Dentro del concepto de frase pueden reunirse entidades expresivas diversas. Las más comunes parecen ser las siguientes 56:

a) Sintagmas nominales: «La emoción de un viaje a la India»; "(Todo quedó en calma). Sólo el murmullo del viento entre las ramas»; «Otra devaluación del peso en puerta»; "Ventajas del matrimonio»; " A la cama inmediatamente! $" 57$.

b) Sustantivos aislados: « ¡Fuego!»; «Una limosnita»; « ¡Socorrol»; «El desmadre».

c) Locuciones hechas (restos o representantes de oración, según algunos autores): «Buenas noches»; «Con su permiso»; «Por favor»; «Hasta la vista»; «A sus órdenes».

d) Formas interjectivas: «Caramba contigo! »; * Ay de mil».

\section{LA PROORACIÓN}

4.1. Llamo así al morfema o sintagma de estructura no oracional que representa - reproduce - una oración gramatical enunciada ante-

35 Frente a lo que sucede en el caso de la cláusula, unidad comunicativa más que gramatical (morfosintáctica), según después veremos.

56 Dado lo reducido del corpus por $\mathrm{ml}$ manejado hasta ahora, esta enumeración no pretende ser exhaustiva ni, mucho menos, definitiva. Sirva sólo de ejemplificación.

57 Así como la estructura oracional típica se organiza en torno a un verbo, la estructura más frecuente de las frases se ordena en torno a un nombre. 
riormente. Aparecen en el discurso como respuesta o comentario a elocuciones previas. Por ejemplo:

«-En mi casa», como respuesta a la pregunta « ¿Dónde nos reuniremos?».

4.2. Cualquier elemento gramatical puede funcionar como prooración:

a) Formas nominales - sustantivo, adjetivo o pronombre- de función nuclear, sujetiva o predicativa, dentro de la oración reproducida:

«(¿Quién se lo dijo?). -Mi hermana»; «(¿Es nuevo o usado?). -Nuevecito»; «( $($ Podría ir alguien?). - Yo mismo».

b) Formas nominales de función complementaria - directa o indirecta- en la oración reproducida:

«(¿Tienes dólares o pesos?). -Dólares»; «( ¿A quién se lo diste?). -A tu sobrinox.

c) Formas adverbiales, o nominales de función adverbial (temporal, modal, locativa, etc.) dentro de la función implicada:

"(¿Cuándo se reunirán?). -Por la noche»; a(¿Y cómo lo resolvieron?). -A lo loco»; «(¿Dónde lo encontraste?). -Alli»; «( ¿Lo tienes tú?). -No»; «(Podríamos hacerlo entre todos). -Tal vez».

4.3. Aunque las prooraciones aparecen normalmente en respuestas dentro del diálogo, pueden presentarse también en otros casos, especialmente en comentarios o especificaciones a lo dicho en la oración representada:

«(Ahi llega. Tengo que esconderme). -Detrd́s de la cortina».

En cuanto entidades gramaticales que representan a una verdadera oración, pueden combinarse sintácticamente con estructuras oracionales plenas, ya como elemento subordinado, ya como subordinante:

«Y cuando le preguntaron si estaba dispuesto a hacerlo, tajantemente les contestó: De ninguna manerax; «(¿Vienes?). -No, porque estoy agotado»; «(¿Dónde nos reuniremos?). -En mi casa, si ustedes no tienen inconvenienten.

\section{EL PERfODO}

5.1. Históricamente, el término período fue empleado por nuestros primeros gramáticos como sinónimo de cláusula, ambos con el sentido 
de expresión completa o semánticamente autónoma. Así, ya, en Jiménez Patón: «Cláusula, ó Periodo se dice una raçon perfeta... \$ ${ }^{5}$. Como también en Sebastián de Covarrubias ${ }^{\text {} 9: ~ « P e r i o d o . ~ L a ~ c l a ́ u s u l a ~ r o d a d a ~ y ~ e n t e r a, ~}$ del nombre griego $\pi \varepsilon p \iota 0 \delta \circ \varsigma$, que es lo mesmo». Igual equivalencia en Correas: «Periodo es palavra Griega... i es lo mesmo que en Latin, i Rromanze clausula». Esta sinonimia se mantuvo hasta el siglo Xxx ${ }^{\infty}$, pero en esa centuria surgen ya los primeros intentos de establecer una distinción entre período y cláusula. Un tanto imprecisos resultan muchos de ellos, como sucede en el caso de Jaime Costa ${ }^{61}$, para quien período sería el enunciado amplio integrado por dos o más cláusulas. De carácter muy similar es la distinción que establecieron algo después Salvador Padilla ${ }^{62}$ y Vicente García de Diego ${ }^{63}$.

En cambio, Gregorio Herrainz ${ }^{64}$ trató de establecer una distinción más precisa y rigurosa. Para él período sería, concreta y específicamente, «la cláusula compuesta de dos partes, la una que expone lo primario del pensamiento (prótasis o principio) dejándolo suspendido y dependiente de la otra, que la completa (apódosis o conclusión). Luego todos los períodos son cláusulas, mas éstas no siempre son períodos». Esta distinción fue aceptada, entre otros gramáticos, por Miguel Jiménez Aquino ${ }^{65} \mathrm{y}$, posteriormente, por Pérez-Rioja ${ }^{66}$.

5.2. Con tales antecedentes, expuestos muy brevemente aquí, considero que puede llamarse periodo a la expresión constituida por dos o más oraciones gramaticales ${ }^{67}$ entre las cuales se establece una sola relación sintáctica, ya coordinante, ya subordinante. Ejemplos: «Trabaja por las mañanas y estudia por las tardes»; «Si vienes a casa, te lo daré».

5.3.1. Por su forma, los períodos pueden ser, de un lado, bimembres o plurimembres, y de otro, simples o compuestos. Normalmente, cada período consta de dos partes o miembros entre los cuales se establece la relación sintáctica única: «Aunque llueva, iremos al campo»;

58 Instituciones de la gramática española, pág. 80v.

59 Tesoro de la lengua castellana o española, Madrid, 1611. (Cito por la ed. de Martín de Riquer, Barcelona, 1943, pág. 135).

0 Salva, Gramática de la lengua castellana, pág. 1.

61 Ob. cit., pág. 141.

62 Gramática histórico-critica de la lengua española, Madrid, 1915, § 264.

63 Manual de gramática castellana, § 274.

64 Gramática castellana, Madrid, 1869, pág. 129.

65 Ensayos de Glosologí. Análisis gramatical de la lengua castellana, Madrid, 1888, pág. 7.

ob Ob. cit., $\$ 284$ y 285.

670 por dos o más frases, o por la combinación de frases y oraciones, como en "Una limosnita, que hoy no he comido nada todavia*. 
«Me lo das o te pego». Pero a veces es posible que aparezcan varios miembros -oraciones o frases o aun prooraciones-, pero siempre unidos por una sola relación sintáctica: «Me lo devuelves, o me lo pagas, o me compras otro igual»; «Llegué, vi y vencí».

Cuando cada miembro del período, sean dos o más, está formado por una sola oración $\longrightarrow$ frase-, el período puede considerarse simple, como es el caso de todos los ejemplos anteriores. Pero si alguno de los miembros del período está constituido a su vez por dos o más oraciones ${ }^{6} \rightarrow$ frases-, el período será complejo. Así, en un enunciado como «Sólo te perdonaré si me devuelves el libro o (si) me lo pagas», existe un período disyuntivo simple («me lo devuelves o me lo pagas») y un período condicional complejo, dado que el miembro condicionante -o prótasis- está formado por dos oraciones: $[(\mathrm{A})-s i(\mathrm{~B}) \circ(\mathrm{C})]=$ [(Te perdono) si (lo devuelves) o (lo pagas)]. El miembro compuesto puede ser también el nuclear o regente: «Lo acepto y lo conservaré siempre, porque me lo das tú». Cosa que había ya observado Gregorio Herrainz ${ }^{\oplus}$, al hablar de miembros paralelos.

5.3.2. No es éste el momento - ni hay espacio para ello- de discurrir pormenorizadamente en torno a los principios teóricos sobre los que se asienta la clasificación sintáctica de los períodos. Es lo que ha hecho la gramática tradicional al clasificar las llamadas xoraciones compuestas» ${ }^{70}$. Sólo considero necesario hacer dos observaciones: una, relativa a la distinción entre oraciones adversativas y oraciones concesivas, cosa en verdad delicada, porque involucra, en cierta medida, los conceptos mismos de parataxis e hipotaxis; la otra, referente a la clasificación de un tipo especial de oraciones, desatendido por lo común en nuestros manuales de gramática.

5.3.2.1. En mi opinión, la diferencia fundamental entre períodos adversativos y perfodos concesivos radica en la relación de causalidad que se establece entre las oraciones de estos últimos, relación ausente en la coordinación adversativa. Dentro de las relaciones causativas -y, por ende, complementarias, subordinadas - cabe distinguir en español - conforme hizo ya Rafael Seco, por ejemplo- la expresión de la causa eficiente, de la causa final, de la causa hipotética y de la causa «con-

68 sea, es a su vez un período diferente.

Ob. cit., pág. 130.

7 Aunque bajo este nombre se reunían confusamente dos tipos de entidades linguísticas: la cláusula y el perfodo. En efecto, las definiciones más comunes de la «oración compuesta - la de la Academia, por ejemplo- corresponden a lo que debe llamarse cláusula ('unidad expresiva autónoma y plena semánticamente'), pero luego, al analizarse y clasificarse esas *oraciones compuestas», no se clasifican las cláusulas, sino los perfodos. 
traria» o contra-causa, lo cual está a cargo de la llamada oración concesiva ${ }^{71}$. Así, en xaunque llueva, iremos al campo», el hecho de que llueva sería causa de no ir al campo, de lo contrario que en la oración principal se afirma. En cambio, en un período adversativo, como « fui a su casa, pero no lo encontré», la oración adversativa (el no encontrar) no es causa - ni contraria ni eficiente- de la otra oración (del ir a su casa).

Los procedimientos un tanto mecánicos con que se trata en la actualidad de delimitar los conceptos de parataxis y de hipotaxis no me parecen convincentes. Así, el hecho de que tal o cual nexo no pueda usarse sino de tal o cual forma podría, en efecto, responder a simples peculiaridades de comportamiento -características particulares de cada forma - sin que ello permita dar a tal comportamiento singular significación suficiente como para definir o caracterizar hechos de orden mucho más profundo y trascendente. No me parece satisfactoria la explicación según la cual los fenómenos de la coordinación y la subordinación quedan definidos por el hecho de que la oración precedida del nexo pueda anticiparse o no a la otra oración; lo primero definiría a la hipotaxis, y lo segundo, a la parataxis. De acuerdo con ello, porque tenía frío sería una oración causal subordinada, ya que no sólo puede decirse "se puso el abrigo porque tenía frío», sino también, anticipando la causal, "porque tenía frío, se puso el abrigo». De aceptar tal criterio de clasificación, resultaría que se cansa pronto sería oración coordinada adversativa cuando fuera introducida por la conjunción pero (en «corre mucho, pero se cansa pronto»), ya que no puede decirse * pero se cansa pronto, corre mucho», y en cambio la misma oración -en idéntica relación con la otra- sería subordinada concesiva cuando fuese introducida por la conjunción aunque, ya que sí puede decirse «aunque se cansa pronto, corre mucho». Creo que los conceptos de coordinación y de subordinación responden a algo más profundo que esa simple posibilidad, que sólo prueba - me parece- el diferente comportamiento particular de los diversos nexos (pero y aunque en este caso). Si la oración coordinada se caracterizara verdaderamente por la obligatoriedad de su posposición y la subordinada por la posibilidad de su anteposición, ¿qué habría de decirse de las oraciones causales introducidas por como, las cuales - al contrario de lo que sucede con las

71 Aunque con otras palabras, casi lo mismo viene a decir Jose LuIs Rivarola en su estudio sobre Las conjunciones concesivas en español medieval y clásico, Tübingen, 1976. Cfr., en especial, pág. 6, donde explica que «un enunciado concesivo expresa un caso en que esa expectativa no se cumple y puede ser definido, así, como contrario a una expectativax. 
demás subordinadas- sólo pueden figurar en la primera posición, pero no pueden posponerse a la oración regente? En efecto, «como tenía frío, se puso el abrigo* es el único orden posible, y no * «se puso el abrigo, como tenía frío. El tener frío es tan causal de ponerse el abrigo como lo sería si se usase puesto que como nexo, el cual sí permite la posposición de la causal.

No creo tampoco que resuelva el problema la fórmula, ya tan difundida, de S. C. Dik ${ }^{\text {?: }}$

\section{Coordinación}

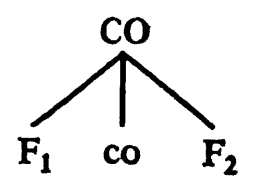

Subordinación

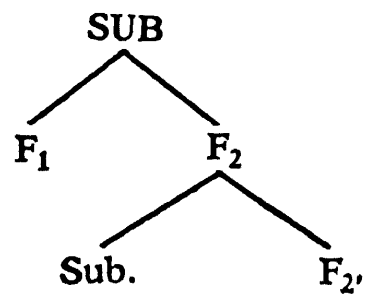

Fórmula que explica la posibilidad de anteposición de la oración subordinada, basándose en la xintegración» del elemento subordinante en el miembro $F_{2}$, pero que no alcanzaría a explicar la simple cuestión de comportamiento singular que impide la posposición de la oración subordinada causal introducida por como. Y que, por otra parte, obliga a hacer razonamientos muy forzados ${ }^{73}$ para mantener a las adversativas dentro de la relación paratáctica, ya que el principio de «permutabilidad» que el esquema de Dik permite en la coordinación ( «Luis y María fueron* = «María y Luis fueron») no funciona bien en el caso de la adversación restrictiva ( Fulano trabaja pero no progresa», algo diferente de «F. no progresa, pero trabaja») y no funciona en absoluto en el caso de adversativas exclusivas relacionadas con sino: En «No es francés sino alemán* no se pueden permutar los miembros sin cambiar totalmente el significado ( «No es alemán sino francés»).

Tampoco el recurso formal de la posibilidad o imposibilidad de coordinación interna entre los nexos subordinantes o coordinantes me parece suficiente para definir los conceptos de hipotaxis y de parataxis. De aceptarlo como válido, habría que clasificar como coordinada la oración causal tenía frío introducida por pues en el enunciado «se acostó pues tenía frío», pero esa misma oración tendría que ser incluida

72 Coordination. Its implications for the theory of general linguistics, Amsterdam, 1968.

73 Como tiene que hacerlos ANA M. Echarde en su estudio sobre «La coordinación adversativa en espaniol», RFE, LVII, 19741975, págs. 1-33; cfr., en especial, págs. 2-8. 
entre las subordinadas si se construyera con puesto que; todo ello, por la sola razón de que pues no admite coordinación consigo misma (* «se acostó, pues tenía frío y pues se sentía cansado»), en tanto que puesto que sí la admite ( $\star$ se acostó, puesto que tenía frío y puesto que se sentía cansadox).

No puede tampoco pasarse por alto el hecho de que esos recursos se contraponen en algunos casos, se anulan: Pues sería coordinante de acuerdo con el criterio de que acabo de comentar, pero en cambio sería subordinante de acuerdo con el criterio de integración en su oración, que permite la anteposición: «Pues lo sabes, no necesitas más explicaciones».

Como bien advierte Rivarola ${ }^{74}$, tanto aunque como pero pueden ser - funcionar como- conjunciones adversativas (coordinantes) o concesivas (subordinantes). $Y$, sin embargo, su comportamiento particular es muy diferente: pero no admite anteposición en la cláusula (* «pero se cansa, corre») ni coordinación interna ( ${ }^{*}$ corre, pero se cansa y pero se ahoga ), cosa que sí es posible con aunque. Creo, pues, que el hecho de que el nexo sea concesivo o adversativo depende del tipo de relación que se establezca entre las dos oraciones, causativa (subordinante) o no causativa (coordinante) respectivamente.

5.3.2.2. En la mayor parte de los manuales de gramática, nada se dice sobre un tipo de oraciones bastante usual en nuestra lengua: el que denominaré «prepositivo», a falta de mejor nombre ${ }^{75}$. Se trata de oraciones que sirven de complemento inmediato -por no decir «directo», ya que la preposición intermedia lo impide- a un verbo de régimen prepositivo. $O$ sea, oraciones del tipo "No me acuerdo de lo que pasó.

Pienso que estas oraciones prepositivas $\rightarrow$ de régimen prepositivo (?) — desempeñan dentro del período una función gramatical equivalente a la de las oraciones objetivas. Si no verdadero complemento directo -objeto- del verbo principal, no cabe duda de que son su término, su complemento inmediato y necesario, tan inmediato y necesario como pueda serlo el complemento directo de los verbos transitivos. Compárense los siguientes ejemplos:

74 Ob. cit., págs. 9-10.

75 AlciNa-Blecun, únicos autores en que encuentro amplia atención a este tipo de oraciones, las llaman «regidas»; cfr. ob. cit., págs. 991-992. También Alarcos (Estudios, págs. 117-118) hace mención de ellas, y Samugl GILI Gaya, Curso superior de sintaxis española, § 224 alude de pasada a este tipo de subordinación. 
(1) No me acuerdo de nada - No recuerdo nada.

No me acuerdo de lo que pasó - No recuerdo lo que pasó.

(2) No me atrevo a decirselo - No oso decirselo.

(3) Me enteré de que se habia ido - Supe que se habia ido.

Prueba de la equivalencia funcional de las oraciones subordinadas de estos períodos, prepositivo y objetivo, es el hecho de que la intuición linguiística de los hablantes se incline a identificarlas, transformando en transitivas a las prepositivas: "Hay que insistir que eso no se les podrá permitir»; "y quedamos que sería interesante hacer la prueba»; «y entonces me entero que se quemó con un soplete» ${ }^{7}$.

Téngase en cuenta, además, que son muchos los verbos castellanos que, siendo antiguamente prepositivos, se han transformado ya en transitivos. Keniston ${ }^{\pi}$ enumera, sólo en el $\S 37.54$ de su obra, los siguientes casos de verbos que, todavía en el siglo XVI, regían la preposición de: aceptar, acordar, creer, desear, determinar, intentar, jurar, olvidar, osar, pensar, procurar, prometer, rehusar y temer. También en el español contemporáneo se advierte la misma tendencia a la construcción directa. $Y$ verbos que en España se mantienen aún como prepositivos, se han hecho transitivos en México: «Platícame eso»; «Te invito unas copas», etc. Desde el punto de vista funcional, habremos de incluir, por lo tanto, estas oraciones prepositivas dentro de la subordinación sustantiva.

5.3.2.3. En resumen, y dadas las finalidades esencialmente prácticas de mis ensayos, la clasificación sintáctica de los períodos que he utilizado ha sido la siguiente:

Periodos paratácticos: a) copulativo; b) ilativo o continuativo; c) distributivo; $d$ ) adversativo -ya restrictivo, ya exclusivo-; $e$ ) disyuntivo.

Periodos hipotácticos: I. - Sustantivos: a) sujetivo; b) predicativo;

c) objetivo; $d$ ) prepositivo; $e$ ) indirecto; $f$ ) adnominal. II. - Adjetivos:

a) explicativo; b) especificativo. III. - Adverbiales: 1) Circunstanciales:

a) temporal; b) modal; c) locativo. 2) Cuantitativos: a) comparativo; b) consecutivo. 3) Causativos: a) causal 78 ; b) final; c) condicional; d) concesivo.

76 En el primer caso puede haber cruce con «repetir que»; en el segundo, con «acordar quew, y en el tercero, con «saber que». Alcina-Blecua recogen un pasaje de Juan Ramón Jiménez similar: «Me acuerdo que me parecian inmensos». Los ejemplos podrían multiplicarse fácilmente.

$\pi$ The syntax of Castilian prose. The sixteenth century, Chicago, 1937.

78 Aunque conceptualmente distintas, las oraciones que expresan la causa lógica y las que expresan la causa eficiente o material pueden construirse en español de igual manera. Entre (1) «Estuvo en tu casa, porque yo lo vi entrar» y (2) «Estuvo en tu casa, porque yo se lo ordené no hay diferencia formal ninguna. Lógicamente sí la hay: en (1), el hecho de que 'yo lo viera' no es la causa determinante de que él 'estuviera en tu casa', en tanto que en (2) el hecho de que 'yo se lo ordenara' si fue lo que determinó que 'él fuera a tu casa'. En el primer caso, el 'haberlo 


\section{LA ORACIÓN COMPUESTA}

6.1. El nombre de «oración compuesta podría reservarse exclusivamente para cierta clase particular de períodos: aquellos en que alguno de los elementos constitutivos de la oración gramatical básica, [S] o $[P]$, es a su vez una oración. Tal cosa sucede, indudablemente, en el caso de los períodos sujetivo y predicativo.

En efecto, si en una oración gramatical - de estructura [S $\leftarrow \mathrm{P}$ ]uno cualquiera de sus elementos nucleares, [S] o [P] o ambos, se transforma a su vez en una oración, el resultado será un sintagma complejo, al que tal vez pueda darse ese nombre de «oración compuesta», por cuanto que evidentemente está compuesto - constituido, formadopor dos componentes oracionales, uno de ellos «encajado» en el otro. Así, en expresiones del tipo

(1) Quien canta su mal espanta.

(2) Tú fuiste el que le engañó

el elemento sujetivo [S] de (1) y el predicativo [P] de (2) están constituidos por una estructura sintáctica que es, en sí misma, una oración gramatical articulada en $[S \leftarrow P]$. Esas oraciones -la sujetiva quien canta de (1) y la predicativa el que me engañó de (2)- son parte constitutiva, nuclear ${ }^{79}$, de cada oración total, verdadera oración compuesta ${ }^{* 0}$.

En cambio, en los otros períodos hipotácticos, la oración subordinada es un simple complemento de la principal, y no un elemento cons-

yo visto' es lo que me permite decir (asegurar, sostener, pensar, etc.) que restuvo en tu casa", de modo que la oración causal «yo lo vi» lo es de un verbo implícito, núcleo lógico de todo el período. (Sobre esto, cfr. el precioso estudio de RafaEL LAPESA, «Sobre dos tipos de subordinación causal», en Estudios ofrecidos a Emilio Alarcos Llorach, III, 1978, págs. 173-205). Se trata, pues, de una diferencia conceptual que no cuenta con diferentes formas de expresión en nuestra lengua. Desde el punto de vista gramatical, las dos oraciones causales se presentan como subordinadas explicativas del predicado principal; la distinción entre ambas - no formal- debe hacerse secundariamente atendiendo a la diferencia lógica o conceptual. Creo, pues, que son dos tipos de una misma clase gramatical de periodos: el causal.

79 OfzLia Kovacci, «Las proposiciones en español», Filología, Buenos Aires, XI, 1965, págs. 23-39; las agrupa entre las «proposiciones incluidas» junto con otras de carácter muy diverso, como (3) «lel el libro que me recomendaste». No cabe duda de que el grado de «inclusión* de quien canta en el ejemplo (1) es muy diferente del de que me recomendaste en (3) $\mathrm{y}$, desde el punto de vista sintáctico, esencialmente distinto.

\$ Doblemente compuesta será, lógicamente, la oración constituida por una subordinada sujetiva y una predicativa: «Quienes lo solucionen bien serán los que podrán pasar a la prueba siguiente». 
titutivo de ella, [S] o [P]. Así, en «leí el libro que me recomendaste», la oración principal tiene plenitud formal por sí misma, puesto que posee un [S] (= yo) y un [P] (= lei el libro) propios y diferentes de la oración subordinada; ésta no es más que un complemento de aquélla, de manera que podría omitirse sin que la regente resultase formalmente cercenada («lé́ el libro»). En cambio, en el período del ejemplo (1) es imposible eliminar la oración sujetiva (quien canta), ya que el sintagma restante (su mal espanta) quedaría formalmente incompleto en cuanto oración, por carecer de su elemento [S] constitutivo, nuclear. $Y$ lo mismo en el caso del período predicativo, ejemplificado en (2). En otras palabras, las oraciones subordinadas sujetivas y predicativas no cumplen, dentro del período, las funciones propias de un elemento secundario dentro de la oración simple, sino las correspondientes a un elemento esencial o constitutivo ${ }^{81}$.

6.2. Tal vez se pueda pensar que no son éstos los dos únicos casos en que quepa hablar de oraciones compuestas. En efecto, los periodos objetivos podrían también considerarse similares a los anteriores:

El elemento nuclear - constitutivo- de oración [P] suele ser un verbo, conjugado o no. $O$ sea, un predicado verbal. Ahora bien, esa identificación de $[P]$ con el (V)erbo es exacta cuando se trata de verbos intransitivos usados intransitivamente, como en «los perros ladran», donde la función de $[\mathrm{P}]$ corresponde exclusivamente al verbo. Cualquier otro elemento que pudiera aparecer en esa oración sería simplemente complementario, no constitutivo de la oración: furiosamente, a la luna, etcétera.

Pero no siempre sucede así. Cuando la oración gramatical está formada por un verbo transitivo usado transitivamente, cabe preguntarse si el elemento esencial del [P] es el verbo o si lo es el complemento directo o si lo es la unión de ambos. En no pocas ocasiones, es evidente que la función predicativa corresponde, en realidad, al complemento directo u objeto. En «Fulano dio un paseon, lo que se predica de Fulano no es el dar, sino el pasear ( = dar + paseo).

Hay varios tipos de estructuras predicativas en que esa función nuclear está a cargo de un nombre - sustantivo o adjetivo- que aparece acompañado por un verbo auxiliar, en rigor no predicativo por sí mismo; el esquema de esas estructuras predicativas es "verbo auxiliar + complemento directo». Entre ellas, las siguientes: «dar + sus-

81 Por supuesto que las oraciones predicativas de carácter adverbial (cfr. lo dicho al final del \$ 2.2.2) deberán también ser incluidas en este grupo: «La leche, donde no pegue el soln. 
tantivo», «hacer + sust.», «tener + sust.» «echar + sust.» * poner + sust.» y otras menos usuales. Ejemplos:

(4) «Fulano dio un suspiro».

(5) «Le hizo una cariciaw.

(6) No tengo ningún temor».

(7) Echale un telefonazo».

(8) Me puso una regañada tremenda».

En todos estos casos, es evidente que la función predicativa no corresponde en rigor a la forma verbal, sino al sustantivo. El verdadero predicado de (4) no es dar, sino dar un suspiro, y el lexema conceptualmente cargado -el que se predica de [S] - no es el verbo, sino el suspiro. En todos esos ejemplos (del 4 al 8), el comunicado predicativo podía haber sido expresado por un verbo derivado de la raíz de cada sustantivo: $*$ dar un suspiro $=$ suspirar, $*$ hacer una caricia $=$ acariciar, etc. La lengua no siempre ha derivado verbos morfológicos para expresar las diversas modalidades conceptuales deducibles de conceptos sustantivos, y por ello muchas perífrasis verbo-nominales carecen de una forma verbal correspondiente. Por ejemplo, «dar un codazo» pero no *codacear; «hacer pucheros» pero no *pucherear, etc.

Paralelamente, la gramática reconoce y establece la existencia de predicados nominales, en los cuales la función [P] corresponde a un nombre, y no al verbo auxiliar (o «copulativo») que pueda acompañarle. Así en

(9) «El perro está hambriento».

(10) «No estoy convencido de ello».

(11) «Fulano es valiente», etc.,

lo que en cada caso se predica de su respectivo sujeto no es, obviamente, ni el ser ni el estar, sino el hambre, la convicción, el valor, etc. Estos predicados nominales funcionan como los verbales $\mathbf{y}$ a veces tienen una expresión léxica paralela: «este chile está muy picante» : : este chile pica mucho ${ }^{82}$.

Pues bien, esas mismas predicaciones pueden establecerse muchas veces a través de la estructura «verbo transitivo auxiliar + sustantivo complemento directo» que estamos considerando:

(9a) «El perro está hambriento - El perro tienen hambre».

(10a) «No estoy convencido - No tengo la conviccion".

(11a) «Fulano es valiente - F. tiene valor».

82 Cfr. Alarcos, Estudios, pág. 120: «el café estaba amargo = el café amargabax, etcétera. 
No pretendo decir que los matices semánticos de ambos tipos de expresiones sean siempre idénticos, ni importa ello gran cosa, sino simplemente que la función de los predicados nominales de la primera serie (hambriento, convencido, etc.) es la misma que la de los sustantivos objetivos de la segunda (hambre, convicción, etc.): la función predicativa. De manera que el elemento [P] de una oración gramatical puede estar constituido simplemente por un verbo -n uso intransitivo- o por un verbo y su complemento directo:

$$
[\mathrm{P}]=\left\{\begin{array}{l}
\mathrm{V}=\mathrm{L} \text { os hombres andan } \\
\mathrm{V}+\mathrm{C} . \mathrm{D} .=\text { Los canguros dan saltos } 83 .
\end{array}\right.
$$

Si se acepta que el elemento [P] de la oración simple transitiva es el conjunto verbo + sustantivo ( $\propto F$. dijo una mentira $={ }^{\prime} F$. mintió $\left.\star\right)$, también el período objetivo -como en «Fulano dijo que vendría debería considerarse como un caso de oración compuesta, dado que el elemento [P] incluiría a su vez una estructura oracional [S $\leftarrow$ P] (él $\leftarrow$ vendria) como parte constitutiva del mismo.

De admitirse esta interpretación, creo que habría que incluir aún, dentro de la clase de «oraciones compuestas», un período más: el formado por oraciones «prepositivas», cuyo funcionamiento sintáctico es similar, como hace poco hemos visto (§ 5.3.2.2), al de las objetivas. Si en «ayer supe la verdad», la función predicativa corresponde a supe la verdad, y en «ayer supe que estaba enfermo» tal función corresponde a supe que estaba enfermo, en «ayer me enteré de que se había quemado», la función predicativa corresponderá a me enteré de que se habia quemado, es decir al verbo regente y a la oración predicativa conjuntamente ${ }^{24}$.

\section{7. la clausula}

\subsection{Historia del concepto en la tradición gramatical española.}

7.1.1. Si bien en la Gramática de Nebrija los términos oración y cláusula aparecen usados indistinta y confusamente (cfr. supra, § 2.1.1),

83 Esta distinción parece haber quedado ya apuntada por Cristóbal de Villalón (cfr. págs. 57.58 y 85). Y años después, mucho más explícitamente, por Gonzalo Correas (págs. 370-371).

34 Esta agrupación de oraciones que denomino "compuestas» me parece secundaria, y no pertenece a la serie de conceptos anteriores (oración, frase, etc.); no se distingue esencialmente del de periodo, sino que es sólo un tipo especial de él. Me limito a señalar tal singularidad y a proponer una denominación para ella. 
en la segunda gran obra gramatical sobre la lengua española, la del Licenciado Villalón, encontramos ya claramente establecida la distinción entre ambos términos y entre los conceptos que cada uno habría de designar en la tradición gramatical hispánica durante los siglos siguientes. Explica Villalón: «deue notar, que ay differençia entre clausula y oraçion. Que oraçión, a lo menos perfecta, se compone por la mayor parte de persona que haze alguna obra: y de verbo: y de persona con quien se denota passar, o hazer aquella obra el verbo... y digo, que clausula es a las vezes vna oraçion sola ${ }^{85}$ y otras vezes es vn ayuntamiento de muchas oraçiones: las quales todas juntas espresan y manifiestan cumplidamente el conçibimiento del hombre en el proposito que tiene tomado para hablar» (pág. 85). Esta precisa distinción es la que sostuvo casi unánimemente la magnífica escuela gramatical española de los Siglos de Oro. Puede hallarse en las obras de Sebastián de Covarrubias $^{*}$ (s. v.), de Jiménez Patón ${ }^{87}$, de Gonzalo Correas ${ }^{88}$, del P. Juan Villar ${ }^{9}$, y del P. Agustín de San Juan ${ }^{\circ}$. Después, a través de Vicente Salvá, ha llegado, en nuestro siglo, a la obra —en esto singular-de Juan B. Selva ${ }^{91}$ y 92 . Baste recordar aquí la explicación del Maestro Correas: «En la Gramatica se llama orazion la rrazon breve i sentido o sentenzia que se haze con nonbre $i$ verbo conzertados con numero $i$ persona... Con las oraziones gramaticales multiplicandose unas tras otras, i muchas vezes mezclandose unas entre otras se haze el periodo, ó corto con pocas oraziones, i a vezes con solo una, ó largo con muchas. Periodo es palavra Griega... i es lo mesmo que en Latin, i Rromanze clausula».

85 El subrayado es mío. De tal observación se desprende, sin lugar a dudas, que Villalón advertía con toda claridad, ya en 1558, la esencial diferencia existente entre oración, en cuanto unidad gramatical, formal, y cláusula, en cuanto unidad de manifestación, nocional. Muchos gramáticos contemporáneos parecen agrupar en un mismo casillero morfosintáctico tan bien diferenciadas entidades lingillsticas.

86 Tesoro de la lengua castellana o española.

87 Ob. cit., págs. 80v. y 81r.

88 Ob. cit., págs. 132 y 135.

* Ob. cit., págs. 235, 253 y 259.

90 Etymologia de los generos, y pretéritos, 2." impression, Valencia, s. a., páginas 223 y 330 .

91 Compendio de gramática, Buenos Aires, 1950. (Cito por la 4.^ ed., Buenos Aires, 1958).

92 La distinción entre cláusula y período, de que nos hemos ocupado en el § 5.1, presupone la distinción entre estos dos conceptos, por un lado, y el de oración, por otro. En consecuencia, el concepto tradicional de cláusula ha sido abrazado, durante las dos últimas centurias, por muchos otros gramáticos: Costa, Padilla, Herrainz, García de Diego, Pérez-Rioja, Lamíquiz, Lingüistica española, 2." ed., Sevilla, 1974. 
7.1.2. Con lo dicho, podrá advertirse fácilmente cuán equivocados estaban Amado Alonso y Henríquez Ureña cuando escribieron aseveraciones tan injustificadas y sorprendentes como éstas: «En algunas gramáticas extranjeras las expresiones que son oraciones por la forma pero no por el sentido se llaman miembros de oración con forma de oración, lo cual en español sería buena explicación pero no un nombre; en las nuestras se suelen llamar, desde Bello, proposiciones para distinguirlas, convencionalmente, de las oraciones plenas. Oración es el término tradicional en nuestras gramáticas para designar la expresión de sentido completo. Por desgracia, algunos gramáticos recientes han introducido otro término, también convencional, cláusula, con el cual designan especialmente a la oración de sentido completo, como si el tener sentido completo fuese cosa de una clase especial de oraciones y no lo normal. Es evidente que, sin embargo, conviene dar el nombre especial a las oraciones especiales, y conservar el nombre tradicional de oración para las oraciones normales. Las oraciones especiales son las que, si bien tienen sujeto y predicado, no tienen sentido completo; y el nombre especial debe reservarse para ellas, como hizo Bello. Muy de desear es que se destierre de nuestras gramáticas el término cláusula, que es impropio, injustificado y provocador de confusiones» (Gram., II, § 19).

Como hemos visto, oración no es el término «tradicional» en la escuela lingǘstica española «para designar la expresión de sentido completo», sino para denominar a la expresión constituida por un nombre y un verbo $\multimap$ un $[S]$ y un $[P]$ - en relación predicativa. Tampoco el término cláusula era una innovación terminológica de comienzos de este siglo, sino voz profundamente enraizada en la tradición hispánica. Y, por último, cláusula - y no oración - fue precisamente el nombre dado por nuestros más antiguos e importantes gramáticos a la «expresión de sentido completox.

No obstante lo erróneo de todas las aseveraciones de Amado Alonso - tan buen conocedor, por otro lado, de las ideas fonéticas de los gramáticos renacentistas-, su injusto anatema parece haber hecho fortuna, en especial desde el momento en que Piccardo y Roca Pons divulgaron ideas semejantes. En la actualidad, los términos tradicionales oración-cláusula han sido prácticamente desplazados por los de proposición-oración empleados - que no ideados- por Bello, cuando no por los correspondientes al uso inglés contemporáneo, cláusula-oración ${ }^{93}$.

93 Inglés clause-sentence. Cfr., por ejemplo, el reciente libro de GuILlarmo Roso, Clausulas y oraciones, Universidad de Santiago de Compostela, 1978, en el que se hace la historia de estos conceptos con un peculiar sentido histórico de nuestra 
Tal desplazamiento me parece, no sólo absolutamente innecesario e injustificado, sino inclusive perjudicial. $Y$ ello, porque no creo que la unidad de la Gramática (o morfosintaxis) sea, de ningún modo, la sentence del inglés - traducida indebidamente con el término oraciónsino la oración de la gramática española tradicional, rebautizada ahora, no ya con un anglicismo, sino con un galicismo: proposición. Pero de ello nos ocuparemos después ( $\$ 8$ ).

\subsection{El concepto de «clausula».}

Recordemos la antigua definición del Licenciado Villalón: «es a las vezes vna oraçion sola: $y$ otras vezes es vn ayuntamiento de muchas oraçiones: las quales todas juntas espresan y manifiestan cumplidamente el conçibimiento del hombre en el proposito que tiene tomado para hablar" $"$. O sea, unidad de manifestación"s que revela un propósito comunicativo $\%$ conceptualmente pleno $\%$.

Para Bello, como para tantos otros gramáticos anteriores o posteriores a él, lo esencial de la cláusula -aunque la denominen oraciónes el hecho de que posee sentido completo. Otros, en cambio, advirtiendo que una caracterización exclusiva o básicamente semántica presenta serios inconvenientes desde el punto de vista gramatical, prefieren atender a su autonomía elocutiva: de ahi las definiciones como expresión en posición absoluta, o sea, no incluida en otra expresión mayor $\$$, o como constituto que no es un constituyente $\$$, o como expresión lingǘstica independiente ${ }^{100}$ que realiza «una verdadera comunicación» ${ }^{101}$.

lingüística: el autor de lengua española más antiguo que se menciona es Andrés Bello (1847) y, de los extranjeros, Arnauld-Lancelot. No sorprende, pues, que la terminología en él empleada sea la inglesa, como lo es ya entre muchos de los profesores de español, no sólo norteamericanos, sino también iberoamericanos y aun espanoles. La dependencia cultural no se limita a los aspectos materiales de la vida moderna.

- Y comparémosla, para advertir mejor su incréble penetración, con la moderna de Sir AlAN GaRDINER, aA sentence is an utterance which makes just as long a communication as the speaker has intended to make before giving himself a rest», The theory of speech and language, Oxford, 2." ed., 1951, pág. 208.

95 Cfr. Lamfourz, ob. cit. (\$ 3.4.1), para quien la cláusula -que él llama enunciado- es ala unidad de manifestación».

* Cfr., de nuevo, GardinER, \&A sentence is a word or set of words revealing an intelligible purpose» (pág. 98).

r El concibimiento del hablante, su pensamiento global; o sea, la expresión «autosemántica», como se preferirla decir hoy.

o Bloomprad, ob. cit., pág. 170.

9 Hocketr, ob. cit., pág. 199.

100 Dicr, ob. cit., pág. 167.

101 Rocu Pons, ob. cit., II, pag. 134.

LXI. -5

(c) Consejo Superior de Investigaciones Cientificas

Licencia Creative Commons 3.0 España (by-nc) 
Todo eso es, en efecto, la cláusula: expresión con autonomía elocutiva - mejor que sintáctica- derivada de su plenitud conceptual.

\subsection{Clasificación previa de las cláusulas.}

7.3.1. Atendiendo al número de sus elementos constitutivos, las cláusulas podrían clasificarse en unimembres o en plurimembres, según que estuvieran integradas por una o por varias unidades gramaticales (oraciones, frases, prooraciones). Ejemplos de cláusulas unimembres: *Me voy a casa». * ¡Silencio! *. *Tanto esfuerzo para nada*. «(¿Quieres venir?) -Desde luego». « ¿Caramba! *. Ejemplos de cláusulas plurimembres: «Aunque no lo creas, ya he leido el libro que me prestaste ayer, porque es apasionante ${ }^{102}$. «( ¿Puedes venir?). - Ahora no, pero mañana sí.

7.3.2. Atendiendo a la naturaleza o clase de sus elementos constitutivos:

A) Cláusulas oracionales: las constituidas por una o varias oraciones gramaticales: «Estoy muy cansado». «Las cuentas, claras, y el chocolate, espeso». «Aunque lo jures, no lo creo, porque es lo más absurdo que he oído nunca y porque tú eres muy mentiroso».

B) Cláusulas no oracionales:

a) Constituidas por frase(s), en cualquiera de sus tipos:

« La esperanza de un regreso feliz!». «Sumisión en su actitud, pero odio en su mirada». " ¡Marfal (vocativo). " Chihuahua!" (interjección). «Buenos días, señor», etc.

b) Constituidas por prooraciones:

- Desde luegol ». *Ahora no, pero mañana sí (cfr. supra).

C) Cláusulas mixtas: Constituidas por combinación de las diversas estructuras gramaticales:

1) Oración y frase:

«Había un vendedor que gritaba: |Al rico bombón heladol». «Tanto trabajo para ganar diez miserables pesos». «Buenos días, dijo al entrar» (cfr. 3.1).

2) Oración y prooración:

«Si lo hará, pero ¿cuándo?». «(¿Tú lo sabes?). -Te juro que no». (¿Lo quieres?). -Si, porque es precioso» (cfr. \$ 4.3).

102 Cláusula constituida por cuatro oraciones, integrantes, a su vez, de tres periodos: concesivo, adjetivo especificativo y causal. 


\section{LA UNIDAD FUNDAMENTAL DE LA GRAMATICA}

8.1. Decía páginas antes ( $\$$ 7.1.2) que el desplazamiento de la distinción oración :: cláusula por la antinomia proposición :: oración me parecía absolutamente inconveniente. Y ello, no sólo como simple cuestión terminológica e histórica, sino también como verdadero error de principio.

En efecto, parece lógico pensar que la unidad fundamental de la gramática, de la morfosintaxis, sea una estructura que pueda definirse morfológica y sintácticamente. El concepto de oración como expresión formada por dos miembros de función diferente, $[S]$ y $[P]$, entre los que se establece una relación predicativa, responde a ese principio morfosintáctico. En cambio, la unidad de manifestación definida como expresión autónoma desde el punto de vista de la elocución, no responde a tal principio, ya que nada dice de la forma gramatical privativa de tales expresiones, ni explica cuál es su función gramatical, pues no creo que la «autonomía elocutiva sea una verdadera función sintáctica. $\mathrm{Y}$, como acabamos de ver, la cláusula - que no «oración - carece de forma gramatical determinada y delimitadora, puesto que puede estar constituida por una sola palabra, o por una prooración, o por una frase, o por una oración gramatical, o por una reiteración de cualquiera de esos elementos o de sus combinaciones. Así, resulta absolutamente imposible determinar cuál pueda ser la forma gramatical de la cláusula ${ }^{103}$.

8.2. Pienso también que la oración, concebida como expresión articulada en [S] y [P] y de relación predicativa, es la unidad fundamental de la gramática por la sencilla razón de que esa estructura ha sido la que ha permitido construir todo el edificio de la ciencia gramatical desde hace siglos. No obstante su actual eclecticismo lógico-semánticogramatical, la Real Academia Española tiene que reconocer que «las oraciones bimembres son las que principalmente han servido y sirven de patrón para el análisis sintáctico, en cuanto establecen una relación formal entre los dos términos del juicio lógico: sujeto y predicado. Cada uno de ellos puede llevar complementos propios que lo determinan

103 ¿Qué tienen en común, desde el punto de vista gramatical, expresiones como * Caray! , por un lado, y, por otro, «Los primeros días, como todos los de boda suelen ser alegres, continuó Lotario como solía la casa de su amigo Anselmo, procurando honralle, festejalle y regocijalle con todo aquello que a él le fue posible, pero acabadas las bodas y sosegada ya la frecuencia de las visitas y parabienes, comenzó Lotario a descuidarse con cuidado de las idas en casa de Anselmo, por parecerle...», etc.? 
y desarrollan, y que se articulan en torno al sujeto o en torno al predicado, como núcleos esenciales de la oración gramatical». Y admite que este concepto estricto de la oración «facilita un instrumento de análisis tan convencional como se quiera, pero que ha sido utilizado con eficacia por la Gramática de todos los tiempos* ${ }^{104}$. La simple determinación de las categorías funcionales de la lengua ha tenido que hacerse siempre partiendo del análisis de la unidad gramatical $[S \leftarrow P]$, según advierte Barrenechea: «Para estudiar las clases de palabras en español con criterio sintáctico tomaremos como base las oraciones bimembres 'sujeto/predicado'. Procederemos así porque en español la estructura de las oraciones unimembres admite cualquier tipo de palabra y de construcción endocéntrica o exocéntrica que podría formar parte de una estructura mayor en el esquema $S / P, y$ por lo tanto no sirve para caracterizar dichas clases ${ }^{105}$.

Cierto es que muchas cláusulas pueden tener verdadera estructura gramatical, pero no en cuanto cláusulas o expresiones autónomas, sino como consecuencia de la estructura propiamente gramatical de las oraciones o periodos que la integren: «Cuando lo vea, se lo daré para que no nos moleste más». Pero tal cosa no sucede en * ¡Socorro! », cláusula verdadera (que no xoración»). Quiero decir que, en el caso de cláusulas oracionales, la estrecha relación de sus elementos constituyentes - consecuencia de haber sido concebidos como un todo por el hablante- determina que puedan ser caracterizadas sintácticamente, dado que entre las oraciones gramaticales que la integran se establecen relaciones sintácticas precisas, de coordinación o de subordinación.

En resumen, si las expresiones predicativas de estructura [S $\leftarrow$ P] son, con mucho, las más usuales en el acto de comunicación; si son ellas las que han permitido levantar el edificio gramatical a través de los siglos; $y$, sobre todo, si todas ellas pueden ser definidas tanto morfológica cuanto sintácticamente, parece lógico que se las considere como la unidad fundamental de la gramática y se reserve para ellas el secularmente tradicional nombre de oración. Esos otros enunciados cuya única característica común es su plenitud conceptual o su autonomía elocutiva, difícilmente podrían ser considerados verdaderas unidades morfosintácticas. Otorgarles ahora el nombre de oración, en vez del tradicional de cláusula, no ofrece ventaja alguna, y sí el grave incon-

104 Real Academia Española, Esbozo de una nueva gramática de la lengua española, Madrid, 1978, § 3.1.6.

105 ANA MARtA BARRENBCHEA, eLas clases de palabras en español, como categorías funcionales». En Estudios de gramática funcional, 2:" ed., Buenos Aires, 1971, pag. 12. 
veniente de presuponer que la unidad básica de la gramática pueda ser una estructura multiforme, heterogénea, y carente de función sintáctica especifica.

\subsection{Oración y proposición.}

Concebida, pues, la oración $\multimap$ expresión bimembre predicativacomo la unidad fundamental ${ }^{106}$ de la Gramática ${ }^{107}$, considero que no habría por qué incluir, dentro de los conceptos gramaticales, el hoy tan generalizado de proposición. Como bien se sabe, con este nombre se designa ahora a toda estructura oracional o predicativa [S $\leftarrow$ P] que carezca de independencia por formar parte de una expresión más amplia. La idea depende del supuesto de que toda oración gramatical debe poseer la autonomía propia... de la cláusula. Pero si la oración se define -como considero gramaticalmente debido- por su forma y su función, sin atender a su autonomía semántica o elocutiva, creo que toda estructura oracional $[S \leftarrow P$ ] seguirá siendo verdadera oración, cualquiera que sea la relación que establezca con otras estructuras oracionales semejantes. Si «Tú te vas» es, indudablemente, una oración, y «Yo me quedo» otra, por cuanto que en ambas se establece una relación predicativa entre un [S] (tú en la primera, y yo en la segunda) y un $[\mathrm{P}]$ (vas y quedo respectivamente), no creo que ninguna de ellas deje de ser lo que gramaticalmente es, por el simple hecho de que se relacionen entre sí en expresiones más amplias (períodos o cláusulas) del tipo: "Tú te vas $y$ yo me quedo», «Tú te vas aunque yo me quedo», "Tú te vas porque yo me quedo», etc. Decir lo contrario es confundir el ser con el actuar ${ }^{100}$. La oración subordinada (o «proposición»), además, puede muchas veces tener plena autonomía, tanto desde el punto de vista formal y elocutivo como desde el punto de vista conceptual o semántico, según puede advertirse en el ejemplo anterior (yo me quedo). $O$ en otros muchos: En «Tú te preocupas demasiado cuando yo estoy enfermo», la oración subordinada tiene plenitud y autonomía formal ( «yo estoy enfermo» es una oración completa por sí misma, que podría

106 Aunque no única, por supuesto, dado que existen otras entidades sintagmáticas, menores y mayores, como locución, frase, periodo, etc.

107 Aunque no tenga por qué serlo de la Semántica, o de la Psicolinguírstica, o de la Estilística, o de la Teoría del lenguaje..., ramas todas de la Linguística con objetivos y metodología especificos, aunque a veces haya quien los mezcle un tanto confusamente.

108 De modo semejante, un sustantivo morfológico, como madera, no deja de ser tal por el hecho de relacionarse -inclusive por subordinación- con otro sustantivo: «puerta de madera»; en cuanto sustantivo, puede seguir rigiendo complementos adjetivos: «puerta de madera tallada», o «de caoba», etc. 
expresarse sola, independientemente) y tiene también sentido completo en sí misma, de manera que el hecho de que forme parte de una expresión más amplia (un período o una cláusula) no cercena en nada el sentido -el contenido semántico- de «yo estoy enfermo» ${ }^{109}$. No me parece aceptable razonar de la siguiente manera: $\mathrm{El}$ enunciado $\alpha \mathrm{Me}$ siento mal» es, sin duda una oración, tanto desde el punto de vista formal [S $\leftarrow \mathrm{P}$ ], como desde el punto de vista de su autonomía elocutiva o de su autonomía semántica. Ahora bien, sí lo coordino o subordino gramaticalmente a otra oración ( $\times$ Me siento mal, pero iré al trabajo» o «Iré al trabajo aunque me siento mal respectivamente), aun conservando toda su plenitud formal y semántica, deja de ser oración por el simple hecho de haber entrado en relación con otra estructura oracional ${ }^{110}$.

Si lo que se quiere decir es que una oración puede yuxtaponerse a otra, o coordinarse con ella o subordinarse a ella, dígase simplemente eso, y llámesela oración yuxtapuesta, oración coordinada u oración subordinada, pero no se la desnaturalice innecesariamente, transformándola en «proposición» "11, para transferir su nombre propio de ora-

109 La posible objeción de que una oración como la de ese ejemplo forma parte de una cláusula y, ast, su autonomía está restringida por tal dependencia o integración, no me parece que tenga validez. También una cláusula o expresión autónoma» puede -y suele - formar parte de un contexto mayor: párrafo, discurso, conversación... de manera que tampoco sería expresión autónoma: Una respuesta del tipo "-Pues no se lo he dicho, porque no lo he visto todavia» es sin duda una cláusula ( $u$ «oración» en términos de Bello) -porque es el enunciado completo del hablante- y sin embargo tiene, obviamente, menos autonomía semántica y aun elocutiva que «estoy enfermo* dentro de su periodo.

110 La posición de quienes opinan que la oración coordinada sí sigue siendo verdadera oración, y no aproposición (cfr. nota 111), me parece todavía menos sostenible. En el ejemplo considerado, lo único que convertiria a me siento mal en «proposición» serfa el hecho de que ya no se ha expresado sola, independientemente (sigue teniendo plenitud formal y autonomía semántica en los dos períodos ejemplificados). Pues bien, ese «no expresarse sola», ese aformar parte de una expresión más amplia» es común tanto al perfodo paratáctico, cuanto al hipotáctico. Como lo es también a la cláusula dentro del discurso.

11 Término, por otra parte, que ni siquiera presenta la ventaja de la economía, pues sus partidarios también se ven obligados a especificar si se trata de proposición coordinada, o subordinada o yuxtapuesta. Cuestión en que, por cierto, tampoco existe acuerdo entre los diversos defensores de la "proposición», ya que para algunos (Escarpanter, como Bloomfield) toda oración relacionada con otra -sea por yuxtaposición, por coordinación o por subordinación- se convierte en proposición (actitud, al menos, rigurosamente sistemática), en tanto que para otros (Roca, Hernández, Marín) sólo a las subordinadas corresponde tal degradación, sin que falte quienes consideren (Alcina-Blecua) que algunas subordinadas son verdaderas oraciones - las complementarias- y sólo las completivas serfan proposiciones (ya que son, estrictamente, las únicas carentes de independencia). No añadiré aquí 
ción a una estructura que puede, inclusive, no ser sintagmática: la cláusula.

Considero, en síntesis, que todo este confuso problema procede de un solo error de principio, el de pensar que la unidad básica de la Gramática- la oración- puede corresponder a una entidad conceptual, informe (o de forma muy variable) y carente de función sintáctica, en vez de identificarse con una estructura formal específica, poseedora de una función sintáctica privativa.

9. Con estas simples y, en su mayor parte, tradicionales estructuras linguísticas -oración, frase, periodo, prooración, cláusula- he hecho algunos intentos de análisis del discurso, y he llegado a resultados que, aunque enteramente provisionales, dada la limitación del corpus analizado ${ }^{112}$, no dejan de ser sintomáticos. He observado, por ejemplo, que la estructura de la cláusula propia del habla culta está mucho más cerca de la estructura de la cláusula literaria, que de la del habla popular. Esa afinidad entre habla culta y lengua literaria, frente a habla popular, se advierte también en lo que respecta a la gran vitalidad de los períodos hipotácticos en las dos primeras, frente a su debilidad en la segunda. He detectado asimismo profundas diferencias entre la estructura de la cláusula peculiar de unos u otros escritores. Pero son éstas cuestiones que no vienen ahora al caso ${ }^{113}$. Las menciono sólo como prueba de la validez práctica, para el análisis gramatical y estilístico, de esas unidades lingüísticas, teórica e históricamente consideradas en las páginas precedentes.

Universidad Nacional de México.

Juan M. Lope Blanch

más. Otras consideraciones sobre el asunto he hecho en el librito publicado por la Universidad de México en 1979 a que hice referencia en la nota 1; a él me remito.

112 Diez breves muestras del habla popular de la ciudad de México, otras tantas del habla culta de la misma ciudad, y otros diez textos escritos por cinco autores mexicanos de nuestro tiempo.

113 Pueden verse en el artículo del Anuario de Letras, XVII, 1979, citado antes (cfr. nota 1). 